\title{
Identifying the optimal depth for mussel suspended culture in shallow and turbid
} environments

\author{
Filgueira, Ramón; Grant, Jon; Petersen, Jens Kjerulf
}

Published in:

Journal of Sea Research

Link to article, DOI:

10.1016/j.seares.2017.11.006

Publication date:

2017

Document Version

Peer reviewed version

Link back to DTU Orbit

Citation (APA):

Filgueira, R., Grant, J., \& Petersen, J. K. (2017). Identifying the optimal depth for mussel suspended culture in shallow and turbid environments. Journal of Sea Research, 132, 15-23.

https://doi.org/10.1016/j.seares.2017.11.006

\section{General rights}

Copyright and moral rights for the publications made accessible in the public portal are retained by the authors and/or other copyright owners and it is a condition of accessing publications that users recognise and abide by the legal requirements associated with these rights.

- Users may download and print one copy of any publication from the public portal for the purpose of private study or research.

- You may not further distribute the material or use it for any profit-making activity or commercial gain

- You may freely distribute the URL identifying the publication in the public portal

If you believe that this document breaches copyright please contact us providing details, and we will remove access to the work immediately and investigate your claim. 


\section{Accepted Manuscript}

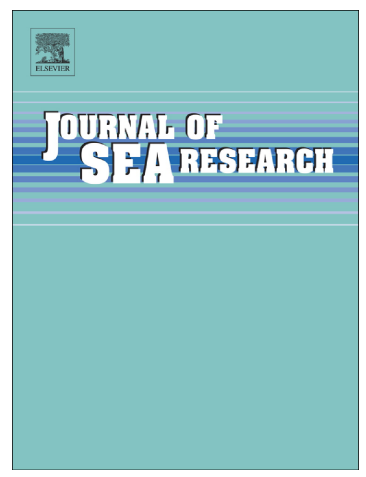

Identifying the optimal depth for mussel suspended culture in shallow and turbid environments

Ramón Filgueira, Jon Grant, Jens Kjerulf Petersen

PII:

S1385-1101(17)30129-6

DOI:

doi:10.1016/j.seares.2017.11.006

Reference:

SEARES 1612

To appear in:

Journal of Sea Research

Received date:

11 May 2017

Revised date:

18 November 2017

Accepted date:

24 November 2017

Please cite this article as: Ramón Filgueira, Jon Grant, Jens Kjerulf Petersen, Identifying the optimal depth for mussel suspended culture in shallow and turbid environments. The address for the corresponding author was captured as affiliation for all authors. Please check if appropriate. Seares(2017), doi:10.1016/j.seares.2017.11.006

This is a PDF file of an unedited manuscript that has been accepted for publication. As a service to our customers we are providing this early version of the manuscript. The manuscript will undergo copyediting, typesetting, and review of the resulting proof before it is published in its final form. Please note that during the production process errors may be discovered which could affect the content, and all legal disclaimers that apply to the journal pertain. 
Identifying the optimal depth for mussel suspended culture in shallow and turbid environments

Ramón Filgueira $^{1, *}$, Jon Grant ${ }^{2}$, Jens Kjerulf Petersen ${ }^{3}$

${ }^{1}$ Marine Affairs Program, Dalhousie University, 1355 Oxford St., P.O. Box 15000,

Halifax, NS B3H 1R2, Canada

${ }^{2}$ Department of Oceanography, Dalhousie University, 1355 Oxford St., P.O. Box 15000,

Halifax, NS B3H 1R2, Canada

${ }^{3}$ The Danish Shellfish Centre, Institute of Aquatic Resources, Technical University of

Denmark, Øroddevej 80, Nykøbing Mors, DK-7900, Denmark

"Corresponding author: Ramon.Filgueira@dal.ca 


\section{Abstract}

Bivalve aquaculture is commonly carried out in shallow water systems, which are susceptible to resuspension of benthic particulate matter by natural processes such as tidal currents, winds and wave action, as well as human activity. The resuspended material can alter the availability of food particles for cultured bivalves. The effect of resuspended material on bivalve bioenergetics and growth is a function of the quality and concentration of resuspended particles and background diet in the water column. Given the potential for positive or negative impacts on bivalve growth and consequently on farm productivity, farmers must position the cultured biomass at the appropriate depth to benefit from or mitigate the impact of this resuspended material. A combination of field measurements, a 1-D vertical resuspension model and a bioenergetic model for mussels based on Dynamic Energy Budget (DEB) theory has been carried out for a mussel farm in Skive Fjord, a shallow Danish fjord, with the aim of identifying the optimal depth for culture. Observations at the farm location revealed that horizontal advection is more important than vertical resuspension during periods with predominant Eastern winds. In addition, high background seston in the water column reduces the impact of resuspension on the available food for mussels. The simulation of different scenarios in terms of food availability suggested minimal effects of resuspension on mussel growth. Based on this finding and the fact that phytoplankton concentration, the main food source for mussels, is usually higher in the upper part of the water column, suspended culture in the top $\sim 3 \mathrm{~m}$ of the water column seems to be the optimal practice to produce mussels in Skive Fjord. Keywords: mussel; aquaculture; resuspension; advection; Dynamic Energy Budget 


\section{Introduction}

The filtration capacity of bivalves cultivated at high densities can effectively reduce the concentration of particles suspended in the water column, which in turn can lead to a reduction in mussel growth (Fréchette and Grant 1991). Suspended culture of bivalves is often carried out in shallow waters, in which natural processes such as tidal currents and wave action as well as human activities such as dredging and trawling can cause resuspension of bottom sediments (Grant et al. 1997) and affect local productivity (Sarà 2009). Bivalves are effectively omnivorous, feeding on microalgae (Bayne et al. 1987, Page and Hubbard 1987), zooplankton (Davenport et al. 2000, Maar et al. 2008), bacteria (Langdon and Newell 1990, Kreeger and Newell 1996), organic detritus (Grant et al. 1997, Safi et al. 2007) and dissolved matter (Manahan et al. 1982, Jørgensen 1983). However, phytoplankton is usually considered the main food source of bivalves due to the higher absorption efficiency compared to other food sources (e.g. Navarro et al. 1996, Babarro et al. 2003). In fact, mussel growth in inner Danish waters that are not highly affected by resuspended bottom material has been simulated using phytoplankton biomass as the only carbon source (e.g. Larsen et al. 2014, Maar et al. 2015). However, the resuspension of benthic detritus, which tends to be of poor quality compared to planktonic food (Fréchette and Daigle 2002), potentially dilutes high quality food sources such as phytoplankton (Cranford 1995). Resuspension can lead to additional pre-ingestive processing costs through pseudofaeces production (Ellis et al. 2002) or to reduction in absorption efficiency (Navarro et al. 1996). The impact of resuspended material on mussel ecophysiology depends on the characteristics and proportion of this material in relation to pelagic suspended material and could be critical for mussel bioenergetics. 
One of the key environmental variables that forces resuspension in shallow waters is wave action caused by wind (Prins et al. 1996, Smaal and Haas 1997, Sarà 2009). The processes related to vertical transport are strongly associated with the stability of the water column, which depend on factors that promote stratification such as surface heating and estuarine circulation, and opposing mixing factors that include tidal mixing, convection, wind stirring and wave stirring. Our study area in the Limfjorden (Denmark) is characterized by shallow depths and frequent resuspension (Lund-Hansen et al. 1999). Wiles et al. (2006) studied the contribution of various factors to water stability measured as the potential energy anomaly (PEA, Simpson and Bowers 1981) in the Limfjorden during late May-early June 2003. They concluded that the major process promoting stratification was surface heating, which is opposed by stirring due to wind through wave motions. An empirical relationship between water column stability ( PEA) and wind speed was also observed by Maar et al. (2010) in Skive Fjord, one of the inner sounds of the Limfjorden and the experimental site of the present study. The periodic switch between stratified and mixed conditions has been used to explain benthic-pelagic coupling between mussel beds and phytoplankton populations in the Limfjorden and more generally mussel bed productivity (Møhlenberg 1999, Wiles et al. 2006, Maar et al. 2010).

Benthic-pelagic coupling in the Limfjorden has been commonly studied in relation to bottom mussel culture production (e.g. Dolmer 2000, Wiles et al. 2006, Maar et al. 2010, Petersen et al. 2013) but to our knowledge there are no studies in which these processes 
have been investigated in relation to suspended mussel culture, a new cultivation technique in the Limfjorden. Long-line culture had been suggested as an alternative and more sustainable technique to traditional dredging in Limfjorden (Dolmer and Frandsen 2002) and the first licenses for suspended culture were approved in late 2004 (Dolmer and Geitner 2004). In the present study, the potential effects of wind-driven resuspended organic material on mussel bioenergetics cultured at different water heights above the seafloor are evaluated following a Dynamic Energy Budget (DEB) approach with the following aims:

- Quantify the potential contribution of resuspended organic material to bivalve growth, and

- Use modelling to determine the potential optimal positioning in the water column for suspended mussel culture.

This use of individual based models as tools to forecast shellfish performance under different environmental conditions is becoming widely accepted (e.g. Thomas et al. 2011) given the potential to evaluate alternative aquaculture scenarios, and their management implications (Nobre et al. 2010; Filgueira et al. 2015). Accordingly, this numerical study should be considered a scoping exercise to a priori identify optimal farming practices, with a posteriori validation of mussel growth required to strengthen the conclusions.

\section{Material and methods}

\subsection{Study area}

Skive Fjord (Fig. 1) is an inner branch of Limfjorden, which is a shallow sound connected to the North Sea on the west coast (32-34 PSU) and to the Kattegat (19-25 
PSU) on the East coast. Skive Fjord has a surface area of $\sim 49 \mathrm{~km}^{2}$ and a mean water depth of $4.7 \mathrm{~m}$. It is a partially mixed estuary with stratification occurring on a scale from days to weeks depending on fresh water input, radiation and wind mixing (Møhlenberg 1999). This locality is characterised as being highly eutrophic with elevated chlorophyll-a concentrations throughout the bivalve growth period and with seasonal hypoxia occurring in late summer (Maar et al. 2010).

A standard commercial long-line unit approximately $250 \times 750 \mathrm{~m}$ (18.8 ha) divided into 3 sections was placed on the western coast in the central part of Skive Fjord (Fig. 1) at 5-7 m water depth. Each section contained 30 long-lines, each $200 \mathrm{~m}$ long, oriented parallel to the coast. The long-lines were kept approx. $0.5-1 \mathrm{~m}$ from the sea surface using buoys and ballast to lift and stabilize the lines.

\subsection{Fieldwork}

A multidisciplinary research was carried out in Skive Fjord during the first two weeks of May 2011 as part of the MuMiHus project (Production of mussels - mitigation and feed for husbandry). Wind speed and direction were collected using a weather station (HOBO Micro Station Logger) located on a floating platform at the farm (Fig. 1). Although the platform was anchored to the seafloor, waves and gusty winds caused slight rotation, introducing uncertainty in wind direction measurements. Therefore, wind direction is considered to provide a general overview of local winds rather than an accurate measurement. Modeled wind speeds for the same area were provided by Karsten Bolding (personal communication) in order to explore the representativeness of our wind data in 
relation to annual wind patterns. At the center of the farm, a mooring with two SCUFA fluorometers with turbidimeters (Turner Designs) positioned at 1 and $1.7 \mathrm{~m}$ above the seafloor and an acoustic FSI 2D-ACM current meter equipped with CTD at $1 \mathrm{~m}$ above the seafloor were deployed from 7 until 12 May. Data collected by the SCUFA at $1.7 \mathrm{~m}$ was impossible to retrieve, probably due to a battery malfunction. Discrete water samples for chlorophyll $a$ concentration $\left(\mu \mathrm{g} \mathrm{l}^{-1}\right)$ and particulate matter $\left(\mathrm{mg} \mathrm{l}^{-1}\right)$ were also collected at $1 \mathrm{~m}$ and $1.7 \mathrm{~m}$ above the seafloor as well as at $1 \mathrm{~m}$ from the sea surface on two consecutive days characterized by different wind speed: 9 and 10 May with low and high winds, respectively. These water samples were collected using a series of siphons attached to the mooring in order to guarantee that the height above the seafloor of sample collection was accurate. The siphons consisted of small tubes through which water was pumped at low rates in order to minimize the impact on water column structure (See Fig. 2 in Petersen et al. 2013 for a detailed description).

Regular monitoring was carried out as part of the MuMiHus project, covering June 2010 until June 2011 at weekly/bi-weekly frequency. At a station in the center of the farm, but not surrounded by longlines, Secchi disk depth as well as chlorophyll and seston samples at two different heights, $1 \mathrm{~m}$ from the sea surface and seafloor, were collected. Fifty $\mathrm{ml}$ of water were filtered through $25 \mathrm{~mm}$ Whatman $\mathrm{GF} / \mathrm{F}$ filters for chlorophyll analysis using $10 \mathrm{ml}$ of ethanol for extraction. Samples were kept frozen $\left(-20^{\circ} \mathrm{C}\right)$ until analysis. Total particulate matter (TPM) and particulate organic matter (POM) were measured gravimetrically on pre-ashed $\left(500{ }^{\circ} \mathrm{C}, 4 \mathrm{~h}\right) 47 \mathrm{~mm}$ Whatman $\mathrm{GF} / \mathrm{F}$ filters by filtering 1000 $\mathrm{ml}$ of water. Filters were dried at $70{ }^{\circ} \mathrm{C}$ for $24 \mathrm{~h}$ and weighed to determine TPM. POM 
was determined after ashing filters for $6 \mathrm{~h}$ at $500{ }^{\circ} \mathrm{C}$. Chlorophyll concentration was converted to carbon units assuming a carbon:chl of 50:1 (Filgueira and Grant 2009). Multiplying POM values by 0.5 and subtracting phytoplankton carbon allowed calculation of detrital carbon (Filgueira and Grant 2009).

\subsection{Vertical distribution of resuspended material}

In the absence of detailed vertical profiles of mussel food, the vertical distribution of total particular matter (TPM) was modelled according to Rose and Thorne (2001), where TPM at $z$ meter height $T P M_{(z)}$ is given by:

$\operatorname{TPM}_{(z)}=\operatorname{TPM}_{(a)} \times\left(\frac{T_{H}-z}{z} \times \frac{a}{T_{H}-a}\right)^{\propto}$

Eq. 1

where $\operatorname{TPM}_{(a)}$ is the supended matter $\left(\mathrm{g} \mathrm{m}^{-3}\right)$ at the reference height $a=1 \mathrm{~m}, T_{H}$ is the tidal height (m), and $\alpha$ is the dimensionless Rouse coefficient, which follows:

$$
\propto=\frac{W_{\operatorname{sink}}}{\beta \times \kappa \times u *}
$$

Eq. 2

where $W_{\text {sink }}=0.622$ (M. Holmer, personal communication) is the seston sinking velocity $\left(\mathrm{m} \mathrm{s}^{-1}\right), \beta=1$ is the dimensionless ratio of sediment diffusivity to eddy viscosity, $\kappa=0.4$ is the von Kármán constant, and $u_{*}$ is the bottom friction velocity ( $\mathrm{m} \mathrm{s}^{-1}$ ). Taking into account the well-known law of the wall, the following equation has been commonly applied to unsteady estuarine and coastal flows (Bricker et al. 2005): 
$\left|U_{(z)}\right|=\frac{\left|u_{*}\right|}{\kappa} \times \ln \left(\frac{z}{z_{0}}\right)$

Eq. 3

where $U_{(z)}$ is the mean velocity $\left(\mathrm{m} \mathrm{s}^{-1}\right.$ ) at height $z$, and $z_{0}$ is the bed roughness length. An approximation to bed roughness length can be derived from the seafloor drag coefficient, $C_{D}:$

$C_{D}=\left(\frac{\kappa}{\ln \left(z / z_{0}\right)}\right)^{2}$

Eq. 4

where $C_{D}=0.0022$ at $1 \mathrm{~m}$ above the bed for muddy sediments (Soulsby 1997).

Combining Eqs. 3 and 4 the following equation is obtained:

$u_{*}^{2}=\left|U_{(z)}\right|^{2} \times C_{D}$

Eq. 5

which, combined with the dimensionless Rouse coefficient (Eq. 2), and applied to Eq. 1 allows the calculation of suspended material at different heights of the water column based on TPM and water speed at the reference height, $1 \mathrm{~m}$. The model was validated using the discrete water samples collected during the fieldwork under different wind regimes.

\subsection{Dynamic Energy Budget model}

The model used in this study is based on Rosland et al. (2009) but parameterized for Danish waters according to Larsen et al. (2014). These versions of DEB assumed 
phytoplankton as the only source of food for mussels. Therefore, the following modifications have been carried out to include organic detritus as a potential source of food for mussels. The $f$ function that scales the energy ingestion rate to the food concentration following a Michaelis-Menten term has been modified to include both phytoplankton and organic detritus:

$f=\frac{X_{p}+\text { pref } \times X_{d}}{X_{K}+X_{p}+p r e f \times X_{d}}$

Eq. 6

where $X_{p}$ and $X_{d}$ are the phytoplankton and organic detritus mass (mg $\mathrm{C} \mathrm{m}^{-3}$ ), $X_{K}$ is the half-saturation coefficient $\left(\mathrm{mg} \mathrm{C} \mathrm{m}^{-3}\right)$, i.e. food concentration when ingestion rate reaches half the maximum rate, and pref is the mussel preferential ingestion for phytoplankton over detritus related to pre-ingestive selection processes. The absorbed energy was calculated by applying a different absorption efficiency to both components of the ingested material, $A E_{p}$ and $A E_{d}$ for phytoplankton and organic detritus, respectively.

The model was run at 11 different heights, $0.1,0.2,0.3,0.4,0.5,1,2,3,4,5$ and $6 \mathrm{~m}$ above the seafloor during the period of the fieldwork (from the 7-12 of May). The resuspension of phytobenthos was assumed to be negligible compared to the abundance of phytoplankton due to limited light at the seafloor (6 $\mathrm{m}$ depth; average Secchi disk depth $\sim 3 \mathrm{~m}$ ). It has been reported that pelagic gross primary production per $\mathrm{m}^{2}$ is approximately 50 times higher than benthic primary production in Skive Fjord at a $5 \mathrm{~m}$ deep site (Krause-Jensen et al. 2012). Given that the seafloor is discounted as a 
significant source of microalgae, the concentration of phytoplankton, $X_{p}$, was assumed to be homogeneous in the entire water column. This assumption is adopted for two reasons: (1) to simplify model parameterization and data required to run the model; and (2) to restrict the uncertainty in the simulations to the main goal of the numerical exercise, i.e., evaluating the potential contribution of resuspended organic matter to mussel growth. Consequently, the chlorophyll values collected at $1 \mathrm{~m}$ above the seafloor, converted to carbon units, were used as $X_{p}$. The concentration of organic detritus at each height above the seafloor, $X_{d}$, was calculated by means of Eq. 1 using the water speed and organic detritus values, converted to carbon units, collected with the turbidimeter at $1 \mathrm{~m}$ above the seafloor as references. The half saturation constant, $X_{K}$, is usually tuned for each experimental location using mussel growth time series data (Rosland et al. 2009, Filgueira et al. 2011). Given the absence of growth data in this short-term study, a range of values, 0,150 and $300 \mathrm{mg} \mathrm{C} \mathrm{m}^{-3}$, have been used to account for the uncertainty in this parameter. A similar approach to account for uncertainty in DEB parameters has been applied to $A E_{p}, 55,70$ and $85 \%, A E_{d}, 25,40$ and $55 \%$, and preferential ingestion of phytoplankton over organic detritus, $0.6,0.8$ and 1 , values that represent pre-ingestive discard of 40,20 and 0\% of organic detritus, respectively. Consequently, the different values of each parameter $X_{K}, A E_{p}, A E_{d}$ and pref, resulted in 81 combinations of parameters that were run for each height above bottom

The effect of the resuspended material on mussel bioenergetics depends not only on the amount of resuspended material but also on the relative concentration of other food sources. Therefore, in addition to the observed conditions during fieldwork, four different 
scenarios in terms of food availability were tested to evaluate the effects of resuspended material on mussel growth depending on environmental conditions. A factorial design with two levels of phytoplankton, $X_{p}$, and two levels of organic detritus, $X_{d}$, was tested repeating the same modelling scheme as described before. The two levels of $X_{p}$ and $X_{d}$ were established based on annual monitoring values at $1 \mathrm{~m}$ above the seafloor, establishing 35 and $360 \mathrm{mg} \mathrm{C} \mathrm{m}^{-3}$ as the low and high level for $X_{p}$, respectively, and 852 and $3067 \mathrm{mg} \mathrm{C} \mathrm{m}^{-3}$ as the low and high level for detritus, respectively. Therefore, the DEB model was run at 11 heights with 81 combinations of parameters and five scenarios in terms of food availability (four related to the factorial design plus the observed conditions), totaling 4455 simulations. The model was initialized with mussels $30.4 \mathrm{~mm}$ shell length and $0.26 \mathrm{~g}$ dry tissue mass. Growth rates were calculated following Clausen and Riisgård (1996):

$\mu=\left(\frac{\mathrm{DTM}_{\mathrm{e}}}{\mathrm{DTM}_{\mathrm{i}}}\right) \times \mathrm{t}^{-1}$

Eq. 7

where $\mathrm{DTM}_{\mathrm{i}}$ and $\mathrm{DTM}_{\mathrm{e}}$ represent the dry tissue mass on the first and last day of the fieldwork, respectively.

\section{Results and discussion}

\subsection{Wind patterns}

The wind pattern during fieldwork (Fig. 2A) revealed a strong component from the East.

This is relevant given the location of the farm and sampling station on the western margin 
of Skive Fjord (Fig. 1). This position together with Eastern winds maximizes the fetch, which can reach $\sim 11 \mathrm{~km}$ given the location of Lovns Bredning, a sub-basin located on Skive Fjord's East margin adjacent to the farming area (Fig. 1). Fetch length along with wind speed is critical for wave formation and consequently for transfer of energy to the water column for advection or sediment resuspension (Booth et al. 2000). Eastern winds peaked at 9-10 $\mathrm{m} \mathrm{s}^{-1}$, almost twice the maximum speed observed for winds from the West. Therefore, during the study period winds not only had a preferential Eastern component but also were strongest when blowing from this direction.

Observed wind direction and speed (Fig. 2A) were in good agreement with modeled data for the same time frame (Fig. 2B). Observed direction is approximately $25^{\circ}$ off the modeled values, which is within the expected error taking into account the positioning of the weather station on a floating platform. In addition, the modeled winds are representative of Skive fjord in general and not of the exact platform positioning, which is locally influenced by the proximity of the coast. Despite these sources of uncertainty, the general agreement suggests that the observed winds can provide a realistic overview of local winds during the study period. In the context of the annual cycle (Fig. 2C), the observed winds during the fieldwork represent the strongest winds with an Eastern component. In a typical year, most of the wind regime has a West-Northwest component followed by an East-Southeast component, with almost negligible contributions from the Northeast and Southwest (Fig. 2C). Therefore, the data collected during the first two weeks of May 2011 represent the oceanographic conditions of a particular wind regime. Consequently, the results of this study cannot be directly extrapolated to situations with 
dominant West-Northwestern winds. Under the latter wind pattern, the proximity of the farm to the coastline significantly reduces fetch length to less than $\sim 200 \mathrm{~m}$, which undoubtedly has an impact on wave energy at the farm site and consequently on potential sediment resuspension.

\subsection{Short-term seston characterization}

Turbidity data at $1 \mathrm{~m}$ above the seafloor indicated a small range over the study period spanning about 6.7-7.5 $\mathrm{mgl}^{-1}$ (Fig. 3A). Despite the low variation, the signal is coherent with the wind patterns given the significant correlation between wind and turbidity at $1 \mathrm{~m}$ above the seafloor. A preliminary plot of the results suggested that the peak turbidity was lagged compared to the East-West peak wind speed. Accordingly, repeated correlation analyses were performed in which the time series of wind (East-West, North-South, and modulus) was progressively lagged in steps of $30 \mathrm{~min}$. The highest correlation $(\mathrm{r}=0.79$, $\mathrm{p}<0.001$ ) was observed between turbidity at time $\mathrm{t}=0 \mathrm{~h}$ and the East-West component of wind speed that occurred at $\mathrm{t}=-9 \mathrm{~h}$ (Fig. 3A). A similar correlation analysis, including lags, was performed between turbidity and both components of current velocity, EastWest and North-South, as well as the modulus of water velocity at $1 \mathrm{~m}$ above the seafloor (Fig. 3B). In this case all Pearson correlation coefficients were below $r=0.12$, which suggests that water velocity and turbidity during the study period were not correlated. As expected, there was no correlation between wind and currents from the same direction, likely due to an additional influence of tides. 
A lag in sediment resuspension following wind speed might be expected due to the time that is needed to transfer energy from the wind to waves and finally to the benthic boundary layer. However, a delay of $9 \mathrm{~h}$ (Fig. 3A) seems excessive to explain a peak of turbidity from resuspended material caused by wind forcing. Moreover, previous work at our study site suggests that wave stress is only felt in the upper $2 \mathrm{~m}$ of the water column (Stevens and Petersen 2011). An alternative hypothesis is to explain these peaks in turbidity in terms of horizontal advection rather than local resuspension forced by wind. This material could be resuspended in other areas of the fjord and transported to the farm by water currents. This hypothesis cannot be tested with current data and would require a detailed hydrodynamic as well as resuspension analysis at the fjord-scale. Another source of turbidity could be resuspension forced by tidal currents but the lack of correlation between turbidity and water velocity (Fig. 3B) does not support this hypothesis, reinforcing the idea of horizontal advection as a potential explanation.

Chlorophyll values from the same instrument were at the lower end of bloom conditions and displayed a greater relative range (3-5 $\left.\mu \mathrm{g}^{-1}\right)$ than turbidity (Fig. 3C). Moreover, they displayed remarkable correspondence to the turbidity record (Fig. 3C), suggesting strong coupling between these water quality parameters. Although chlorophyll would contribute to mass measured with turbidity, the chlorophyll concentration measured herein would not form a large proportion of the observed turbidity of $\sim 7 \mathrm{mg}^{-1}$. Instead, these results indicate similar particle dynamics for both variables, which is discussed below in the context of the relative importance of horizontal advection and resuspension. 


\subsection{Long-term seston characterization}

It has been demonstrated that stratification and mixing of the water column is strongly related to wind forcing in the Limfjorden (Wiles et al. 2006, Maar et al. 2010). Our study has focused on the concomitant effects of wind forcing on benthic resuspension and consequently on bivalve growth (e.g. Witbaard et al. 2005). Previous studies of this site indicated a two-layer structure which isolates mussel culture from the lower half of the water column (Nielsen et al. 2106; Stevens and Petersen 2011). There is however, both temporal and spatial variability in stratification, including interaction with farm infrastructure, and it is difficult to categorize farm conditions as mixed or stratified (Stevens and Petersen 2011). However, water sampling helps make this distinction with regard to mussel food supplies, providing a spatial aspect to seston dynamic s in addition to the temporal component discussed above.

Regular monitoring of the station at the mussel farm suggests that the top part of the water column ( $1 \mathrm{~m}$ from the sea surface) is often enriched in chlorophyll compared to the bottom ( $1 \mathrm{~m}$ above the seafloor) (Fig. 4A), despite the fact that both sampling points are only $\sim 4 \mathrm{~m}$ apart in the water column (average depth $\sim 6 \mathrm{~m}$ ). Top and bottom chlorophyll concentrations are not correlated (Fig. 4A). This lack of correlation and the higher values of chlorophyll in the upper part of the water column could be related to light availability and seasonal stratification. The average Secchi depth at this station was $\sim 3 \mathrm{~m}$ which indicates relatively high turbidity and reduced light penetration in the water column, limiting the euphotic zone to surface waters. Moreover, it suggests that lack of light on the bottom would not favor a benthic microalgal community available for resuspension. 
These long-term monitoring results support discounting the bottom of the fjord at this site as a potential source of benthic microalgae and are aligned with previous observations showing that benthic gross primary production is negligible compared to pelagic production (Krause-Jensen et al. 2012). However, under high wind conditions, vertical mixing and horizontal advection of chlorophyll-rich waters may enrich chlorophyll in the bottom layer.

With regard to detrital carbon, the significant correlation coefficient (Fig. 4B) suggests that both the top and bottom of the water column follow the same pattern through time. In addition, given the significant reduced major axis regression with slope and intercept statistically similar to 1 and 0 , respectively (Fig. 4B), the long-term monitoring indicates that detrital $\mathrm{C}$ in the top and bottom are statistically similar. However, the regression only explains $35 \%$ of the variance, suggesting significant variability in the dataset and the relevance of short-term variation in detrital carbon in the water column. These results do not neglect the effect of short-term resuspension on detrital $\mathrm{C}$ concentration at the bottom but highlight that due to horizontal advection or vertical mixing processes, the detrital $\mathrm{C}$ concentration in the top and bottom are similar in the long term.

The lack of correlation between detrital carbon and phytoplankton-derived carbon at both heights suggests that both sources of carbon follow different patterns through time (Fig. 4C and 4D for top and bottom, respectively). Long term monitoring showed that it is possible to find low or high phytoplankton concentration independently of detritus concentration and vice versa. This observation is crucial to define potential scenarios in 
terms of food availability for the modelling exercise to cover all potential trophic situations and extend the scope of the study beyond the period covered by the fieldwork.

\subsection{Seston vertical profiles}

Despite the fact that the pattern in turbidity at $1 \mathrm{~m}$ height above the seafloor seems unrelated to resuspension forced by currents during the fieldwork, changes in water speed could modulate the vertical profile of turbidity at the local scale. The Rose and Thorne (2001) equations to predict total particulate matter at different heights were applied to both days in which discrete samples of water were collected, on 9 and 10 May. The shortterm characterization of TPM from the turbidimeter located at $1 \mathrm{~m}$ above the seafloor was converted to POM using a constant ratio, which resulted in POM values between 2650 and $2900 \mathrm{mg} \mathrm{C} \mathrm{m}^{-3}$ (Fig. 3A). The predictions suggest maximum concentrations of POM in bottom waters, 2775 and $2990 \mathrm{mg} \mathrm{C} \mathrm{m}^{-3}$, and minimum in surface waters, 2520 and $2485 \mathrm{mg} \mathrm{C} \mathrm{m}^{-3}$, for 9 and 10 May, respectively (Fig. 5). These concentration gradients represent a change of 9.6 and $18.4 \%$ in POM between top and bottom for these two days, respectively. This POM gradient is consistent with the discrete samples that were collected on both days (Fig. 5). However, contrary to expectations, the sample collected at $1.7 \mathrm{~m}$ above the seafloor showed the lowest concentration on both days (Fig. 5). Nevertheless, POM at $1.7 \mathrm{~m}$ was statistically similar to the other samples, at $1 \mathrm{~m}$ above the seafloor and from the sea surface on both sampled days. These results suggest that the natural variation is higher than the vertical gradient in the water column that was forced by hydrodynamic conditions during the study. This constraint is critical for the full validation of Rose and Thorne (2001) equations in the context of this study. Despite the 
fact that the equations predict a logical pattern that matches observations (Fig. 5), the absence of statistical differences within the water column calls for further field measurements under wider environmental conditions to fully validate Rose and Thorne (2001) equations for Skive Fjord.

In summary, there are four potential sources of organic material in the water column, primary production, local resuspension forced by winds and wave action (Smaal and Hass 1997), local resuspension forced by water currents (Rose and Thorne 2001) and horizontal advection. We to emphasize the importance of local environmental conditions in understanding the seston dynamics in Skive Fjord. During the $6 \mathrm{~d}$ fieldwork, POM varied between 2650 and $2900 \mathrm{mg} \mathrm{C} \mathrm{m}^{-3}$ at $1 \mathrm{~m}$ above the seafloor according to the turbidimeter (Fig. 3A) and the maximum vertical gradient between 2550 and $2900 \mathrm{mg}$ C $\mathrm{m}^{-3}$ according to in situ water sampling (Fig. 5). These values suggest relatively high levels of turbidity and a narrow range of variation in this area during the study period. Under these circumstances, the influence of wind- and/or current-forced resuspension are diluted by the high background seston, including phytoplankton, and masked within the natural variation, which makes it challenging to focus on resuspension-related hypotheses. Our data indicate decoupling of both chlorophyll and POM in surface compared to bottom waters, indicative of vertical stratification although not necessarily resuspension. For surface waters, coherence between these two particle sources suggests similar dynamics, horizontal advection being the most plausible explanation. However, this hypothesis needs to be tested in future fieldwork. This information has been used to define the available food for mussels in the water column. 


\subsection{Mussel bioenergetics at different heights above the seafloor}

In addition to the environmental conditions observed during the fieldwork in May 2011, four additional scenarios in terms of food availability were coupled to DEB in order to expand the scope of this study beyond the time period of the fieldwork. These scenarios were constructed based on long-term monitoring carried out during the MuMiHus project (see above). Two key assumptions were made to define microalgal availability for mussels in the DEB model. Firstly, phytobenthos were considered negligible, which is plausible according to the Secchi depths and previous studies that reported a minor contribution of benthic gross primary production to the total production in Skive Fjord (Krause-Jensen et al. 2012). Secondly, the water column was considered homogeneous in terms of phytoplankton availability, which is not necessarily valid the whole year based on the long-term monitoring data (Fig. 4A). In $28.6 \%$ of the sampling dates (paired ttests), phytoplankton concentration was significantly higher in the top than in the bottom part of the water column, which suggests that the model could penalize the growth of mussels allocated in the upper region. Accordingly, the model properly represents $72.4 \%$ of the environmental conditions observed in the fjord. Nevertheless, higher phytoplankton concentration in the upper zone should be included in a precautionary approach to management when recommending optimal positioning in the water column for suspended culture.

The outcomes of the DEB model suggest typical growth rates for cultured mussels (Maar et al. 2010, Larsen et al. 2014), but that effect of height above the seafloor on mussel 
growth rate is highly dependent on environmental conditions (Fig. 6). When phytoplankton concentration is low, $35 \mathrm{mg} \mathrm{C} \mathrm{m}^{-3}$ according to the lowest values observed in the regular term monitoring (Fig. 4A), detrital carbon could become a significant food source for mussels. Therefore, under reduced phytoplankton conditions, mussels located close to the bottom could potentially benefit from the higher concentration of detritus compared to surface waters (Fig. 6A and 6B). This pattern is reversed when phytoplankton levels increase (Fig. 6D and 6E) given that under these conditions detrital carbon dilutes high quality food, i.e. phytoplankton (Cranford 1995, Fréchette and Daigle 2002). The potential dilution of high quality food can be also observed when comparing the effect of detritus concentration for a fixed level of phytoplankton. For example, at reduced phytoplankton levels (comparing Fig. 6A vs 6B), the highest amount of detritus (Fig. 6B) results in $11.7 \%$ higher growth rate at the bottom than the lowest amount of detritus (Fig. 6A); meanwhile at high phytoplankton concentration (comparing Fig. 6D vs $6 \mathrm{E}$ ), the increase in detritus (Fig. 6D) reduces mussel growth rate at the bottom by $16.6 \%$ compared to the scenario with low detritus (Fig. 6E).

Despite the simulated vertical trends in mussel growth depicted by the DEB model coupled to Rose and Thorne (2001) equations, the modelling results suggest that the impact of height above the seafloor on mussel growth rate is minor. The maximum vertical change in mussel growth rate would be observed under high phytoplankton and low detritus conditions (Fig. 6E), which would cause a reduction in growth rate of $-2.6 \%$ at the bottom compared to mussels grown near the sea surface. The latter scenario represents the ideal situation in terms of environmental conditions to promote bivalve 
growth and consequently maximize the effect of height above the seafloor on bivalve physiology. The simulation of bivalve growth at different heights during the fieldwork (Fig. 6C) suggested a low impact of vertical positioning on mussel growth rates, with a reduction of $-0.65 \%$ at the bottom compared to the top. The reduced impact of height above the seafloor on mussel growth is related to the small contribution of resuspended material compared to the high background concentration of detrital matter, as discussed above. These results highlight the high food availability of the study area for mussel culture, in good agreement with Nielsen et al. (2016), who estimated that population filtration rate in this study area could be increased by $80-120 \%$ without negative feedback on mussel growth caused by food depletion.

\section{Conclusions}

The conclusions of this study should be carefully considered due to the extent of estuarine oceanographic variability in complicating resolution of potential sources of detrital matter in the water column: local resuspension forced by winds and wave energy, local resuspension forced by water currents and horizontal advection. To circumvent this methodological challenge, further studies should focus on periods in which the relative contribution of resuspended material may be higher than the background seston. An investigation of these processes would also benefit from a hydrodynamic model, to understand the source and fate of advected material. In addition, the DEB model does not include the energetic costs of pre-ingestive sorting and pseudofaeces production, which can be significant during resuspension events that increase the concentration of available seston (Ellis et al. 2002). Further simulations should improve the 
parameterization/validation under specific local conditions, including experiments to determine pseudofaeces production and individual energy budgets under extreme conditions in terms of food availability. Additional growth experiments of bivalves located at different heights above the seafloor in various areas of the fjord would help to validate the model under different environmental conditions. This approach would strengthen the outcomes of this study and increase the applicability of the model to address farm- and ecosystem-scale questions such as farm production and carrying capacity, respectively.

Despite these sources of uncertainty, the results collected for the MuMiHus project during the regular long-term monitoring and short-term fieldwork together with a scenario analysis of extreme conditions following a factorial design, provide a robust approach to coupling seston dynamics to cultured mussel growth. Given that resuspended material did not alter the background carbon suspended in the water column, it is expected that the contribution of resuspended material to a mussel's diet is negligible in this case. Taking this into consideration the observation that chlorophyll concentration is usually higher in the upper than in the lower part of the water column in the long term (Fig. 4A), it seems prudent to focus farming activities in the upper part of the water column. This option would also circumvent the potential food limitation in bottom waters due to strong vertical stratification and reduced coupling with the more productive upper layers, which has been observed for bottom culture (Maar et al. 2010). Nevertheless, culture could be extended to some degree to deeper waters without major negative effects on mussel growth. However, this expansion should also consider the risks related to 
potential anoxic events in the bottom layers as well as the presence of predators, i.e. crabs or starfish, which could compromise the viability of these practices. In addition, this potential expansion to deeper waters would increase operational costs, infrastructure and labor, which should be included in a thorough economic analysis to evaluate the viability of the expansion. Given (1) the capacity of the system to provide food for mussels (Nielsen et al. 2016); (2) the negligible contribution of resuspended material to their diet; and (3) the potential increase in operational costs and risks, the main recommendation in the context of culture management is to restrict farming activities to the top part of the water column, confirming existing practices. Finally, this case study in Skive Fjord demonstrates the capabilities of coupling bivalve DEB to a resuspension model to evaluate farming practices in shallow cultivation areas or to other cultivation techniques in which vertical position in the water column could be relevant for maximizing production.

\section{Acknowledgements}

We would like to thank two anonymous reviewers for their constructive and valuable feedback. This study is part of the research project "Production of Mussels - Mitigation and Feed for Husbandry (MuMiHus)" funded by the Danish Council for Strategic Research under grant agreement no. 09-066983. Further support was provided by the Natural Sciences and Engineering Research Council of Canada.

\section{References}


Babarro JMF, Fernández-Reiriz MJ, Labarta U. 2003. In situ absorption efficiency processes for the cultured mussel Mytilus galloprovincialis in Ría de Arousa (northwest Spain). J. Mar. Biol. Ass. U.K. 83:1059-1064.

Bayne BL, Hawkins AJS, Navarro E. 1987. Feeding and digestion by the mussel Mytilus edulis L. (Bivalvia: Mollusca) in mixtures of silt and algal cells at low concentrations. J. Exp. Mar. Biol. Ecol. 111:1-22.

Booth JG, Miller RL, McKee BA, Leathers RA. 2000. Wind-induced bottom sediment resuspension in a microtidal coastal environment. Cont. Shelf Res. 20:785-806.

Bricker JD, Inagaki S, Monismith SG. 2005. Bed drag coefficient variability under wind waves in a tidal estuary. J. Hydraul. Eng. 131:497-508.

Clausen IB, Riisgård HU. 1996. Growth, filtration and respiration in the mussel Mytilus edulis: no evidence for physiological regulation of the filter-pump to nutritional needs. Mar. Ecol. Prog. Ser. 141:37-45.

Cranford PJ. 1995. Relationships between food quantity and quality and absorption efficiency in sea scallops Placopecten magellanicus (Gmelin). J. Exp. Mar. Biol. Ecol. 189:123-142.

Davenport J, Smith RJ, Packer M. 2000. Mussels Mytilus edulis: significant consumers and destroyers of mesozooplankton. Mar. Ecol. Prog. Ser. 198:131-137.

Dolmer P. 2000. Feeding activity of mussels Mytilus edulis related to near-bed currents and phytoplankton biomass. J. Sea Res. 44:221-231.

Dolmer P, Geitner K. 2004. Integrated Coastal Zone Management of cultures and fishery of mussels in Limfjorden, Denmark. ICES CM 2004/V:07

Dolmer P, Frandsen RP. 2002. Evaluation of the Danish mussel fishery: suggestions for 
an ecosystem management approach. Helgol. Mar. Res. 56:13-20.

Ellis J, Cummings V, Hewitt J, Thrush S, Norkko A. 2002. Determining effects of suspended sediment on condition of a suspension feeding bivalve (Atrina zelandica): results of a survey, a laboratory experiment and a field transpant experiment. J. Exp. Mar. Biol. Ecol. 267:147-174.

Filgueira R, Grant J. 2009. A box model for ecosystem-level management of mussel culture carrying capacity in a coastal bay. Ecosystems 12:1222-1233.

Filgueira R, Rosland R, Grant J. 2011. A comparison of scope for growth (SFG) and dynamic energy budget (DEB) models applied to the blue mussel (Mytilus edulis). J. Sea Res. 66:403-410.

Filgueira R, Guyondet T, Bacher C, Comeau LA. 2015. Informing Marine Spatial Planning (MSP) with numerical modelling: a case-study on shellfish aquaculture in Malpeque Bay (Eastern Canada). Mar. Poll. Bull. 100:200-216.

Fréchette M, Grant J. 1991. An in situ estimation of the effect of wind-driven resuspension on the growth of the mussel Mytilus edulis L. J. Exp. Mar. Biol. Ecol. 148:201-213.

Fréchette M, Daigle G. 2002. Reduced growth of Iceland scallops Chlamys islandica (O.F. Müller) cultured near the bottom: a modelling study of alternative hypotheses. J. Shell. Res. 21:87-91.

Grant J, Cranford P, Emerson C. 1997. Sediment resuspension rates, organic matter quality and food utilization by sea scallops (Placopecten magellanicus) on Georges Bank. J. Mar. Res. 55:965-994. 
Jørgensen CB. 1983. Patterns of uptake of dissolved amino acids in mussels (Mytilus edulis). Mar. Biol. 73(2):177-182.

Kreeger DA, Newell RIE. 1996/ Ingestion and assimilation of carbon from cellulolytic bacteria and heterotrophic flagellates by the mussels Geukensia demissa and Mytilus edulis (Bivalvia, Mollusca). Aquat Microb Ecol 11:205-214.

Krause-Jensen D, Markager S, Dalsgaard T. 2012. Benthic and pelagic primary production in different nutrient regimes. Estuar. Coasts 35:527-545.

Langdon CJ, Newell RIE. 1990. Utilization of detritus and bacteria as food sources by 2 bivalve suspension-feeders, the oyster Crassostrea virginica and the mussel Geukensia demissa. Mar. Ecol. Prog. Ser. 58:299-310.

Larsen PS, Filgueira R, Riisgård HU. 2014. Somatic growth of mussels Mytilus edulis in fiel studies compared to predictions using BEG, DEB and SFG models. J. Sea Res. 88:100-108.

Lund-Hansen LC, Petersson M, Nurjaya W. 1999. Vertical sediment fluxes and waveinduced sediment resuspension in a shallow-water coastal lagoon. Estuaries 22: 3946.

Maar M, Nielsen TG, Petersen JK. 2008. Depletion of plankton in a raft culture of Mytilus galloprovincialis in Ria de Vigo, NW Spain. II. Zooplankton. Aquat. Biol, 4(2):127-141.

Maar M, Timmermann K, Petersen JK, Gustafsson KE, Storm LM. 2010. A model study of the regulation of the blue mussels by nutrient loadings and water column stability in a shallow estuary, the Limfjorden. J. Sea Res. 64:322-333. 
Maar M, Saurel C, Landes A, Dolmer P, Petersen JK. 2015. Growth potential of blue mussels (M. edulis) exposed to different salinities evaluated by a Dynamic Energy Budget model. J. Mar. Syst. 148:48-55.

Manahan DT, Wright SH, Stephens GC, Rice MA. 1982. Transport of dissolved amino acids by the mussel, Mytilus edulis: demonstration of net uptake from natural seawater. Science 215:1253-1255.

Møhlenberg F. 1999. Effect of meteorology and nutrient load on oxygen depletion in a Danish micro-tidal estuary. Aquat. Ecol. 33:55-64.

Navarro E, Iglesias JIP, Pérez Camacho A, Labarta U. 1996. The effect of diets of phytoplankton and suspended bottom material on feeding and absorption of raft mussels (Mytilus galloprovincialis Lmk). J. Exp. Mar. Biol. Ecol. 198:175-189.

Nielsen P, Cranford PJ, Maar M, Petersen JK. 2016. Magnitude, spatial scale and optimization of ecosystem services from a nutrient extraction mussel farm in the eutrophic Skive Fjord, Denmark. Aquacult. Envir. Interact. 8: 311-329.

Nobre AM, Ferreira JG, Nunes JP, Yan X, Bricker S, Corner R, Groom S, Gu H, Hawkins A, Hutson R, Lan D, Lencart e Silva JD, Pascoe P, Telfer T, Zhang X, Zhu M. 2010. Assessment of coastal management options by means of multilayered ecosystem models. Estuar. Coast. Shelf Sci. 87:43-62.

Page HM, Hubbard DM. 1987. Temporal and spatial patterns of growth in mussels Mytilus edulis on an offshore platform - relationships to water temperature and food availability. J Exp 111, 159-179. 
Petersen JK, Maar M, Ysebaert T, Heran PMJ. 2013. Near-bed gradients in particles and nutrients above a mussel bed in the Limfjorden: influence of physical mixing and mussel filtration. Mar. Ecol. Prog. Ser. 490:137-146.

Prins TC, Smaal AC, Pouwer AJ, Dankers N. 1996. Filtration and resuspension of particulate matter nad phytoplankton on an intertidal mussel bed in the Oosterschelde estuary (SW Netherlands). Mar. Ecol. Prog. Ser. 142:121-134.

Rose CP, Thorne PD. 2001. Measurements of suspended sediment transport parameters in a tidal estuary. Con. Shelf Res. 21:1551-1575.

Rosland R, Strand Ø, Alunno-Bruscia M, Bacher C, Strohmeier T. 2009. Applying dynamic energy budget (DEB) theory to simulate growth and bio-energetics of blue mussels under low seston conditions. J. Sea Res. 62:49-61.

Safi KA, Hewitt JE, Talman S. 2007. The effect of high inorganic seston loads on prey selection by the suspension-feeding bivalve, Atrina zelandica. J. Exp. Mar. Biol. Ecol. 344:136-148.

Sarà G. 2009. Variation of suspended and sedimentary organic matter with depth in shallow coastal waters. Wetlands 29:1234-1242.

Simpson JH, Bowers D. 1981. Models of stratification and frontal movement in shelf seas. Deep-Sea Res. Part A-Oceanogr. Res. Pap. 28:727-738.

Smaal AC, Haas HA. 1997. Seston dynamics and food availability on mussel and cockle beds. Estuar. Coast. Shelf Sci. 45:247-259.

Soulsby R. 1997. Dynamics of marine sands: a manual for practical applications. Thomas Telford Publications, London, p 253. 
Stevens CL, Petersen JK. 2011. Turbulent, stratified flow through a suspended shellfish canopy: implications for mussel farm design. Aquacult. Environ. Interact. 2:87-104.

Thomas Y, Mazuri J, Alunno-Bruscia M, Bacher C, Bouget J-F, Gohin F, Pouvreau S, Struski C. 2011. Modelling spatio-temporal variability of Mytilus edulis (L.) growth by forcing a dynamic energy budget model with satellite-derived environmental data. J. Sea Res. 66:308-317.

Wiles PJ, van Duren LA, Häse C, Larsen J, Simpson JA. 2006. Stratification and mixing in the Limfjorden in relation to mussel culture. J. Mar. Syst. 60:129-143.

Witbaard R, Duineveld GCA, Amaro T, Bergman MJN. 2005. Growth trends in three bivalve species indicate climate forcing on the benthic ecosystem in the southeastern North Sea. Clim. Res. 30:29-38. 


\section{Figure Legends}

Figure 1. (A) Position of Skive Fjord within the Limfjorden, and (B) position of the farm within Skive Fjord.

Figure 2. Wind rose diagram for (A) observed winds during the fieldwork carried out during the first two weeks of May 2011; (B) modeled winds for the same time period, and; (C) modeled winds for 2011. Coloured categories represent wind speed in $\mathrm{m} \mathrm{s}^{-1}$. Figure 3. Temporal pattern of (A) turbidity at $1 \mathrm{~m}$ above the seafloor and wind speed observed 9 hours before the specified time, which is the time lag that maximizes the correlation between wind speed and turbidity $r=0.79, \mathrm{p}<0.001)$; (B) water velocity and turbidity at $1 \mathrm{~m}$ above the seafloor; and (C) chloropohyll and turbidity at $1 \mathrm{~m}$ above the seafloor. Dashed lines represent when discrete water samples were taken and the black dots indicate the observed turbidity at $1 \mathrm{~m}$ above the seafloor.

Figure 4. Correlation analysis between chlorophyll and detrital $\mathrm{C}$ at both heights above the seafloor. Pearson's correlation coefficient and p-values are shown for the pairs (A) chorophyll top vs bottom, (B) detrital C top vs bottom, (C) detrital C top vs chlorophyll top, and (D) detrital C bottom vs chlorophyll bottom. Dashed line with slope of 1 in (A) and (B). Solid line represents reduced major axis regression in (B).

Figure 5. Vertical profile of particulate organic matter on 9 and 10 of May. Continuous lines represent predictions using Rose and Thorne (2001) equations. Crosses represent observations (mean \pm standard deviation).

Figure 6. Simulated growth rate of Mytilus edulis in the water column under five different scenarios in terms of food availability (A to E). The growth rate at each height above the seafloor has been averaged for the 81 combinations of DEB parameters. Linear 
interpolation has been used to construct a continuous vertical profile although only 11 heights have been simulated. 


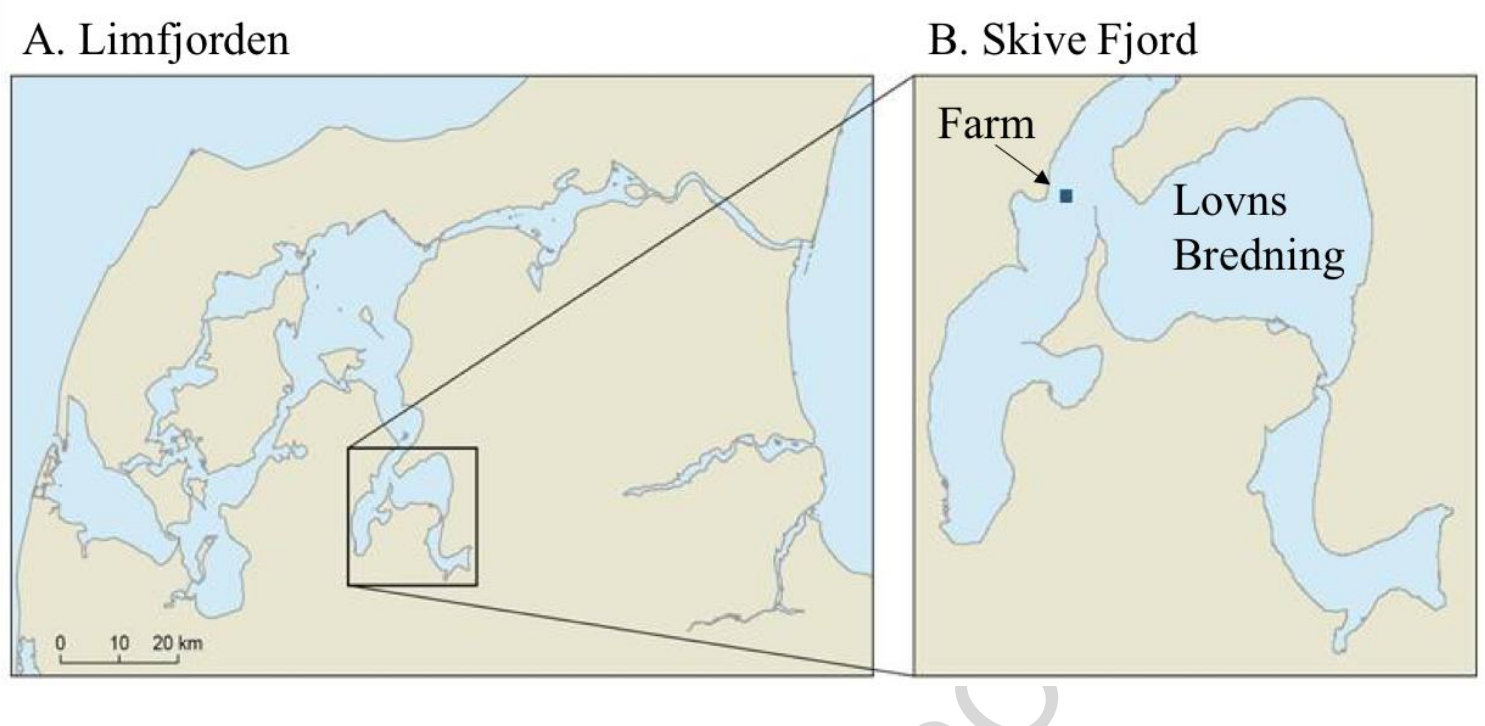

Figure 1 


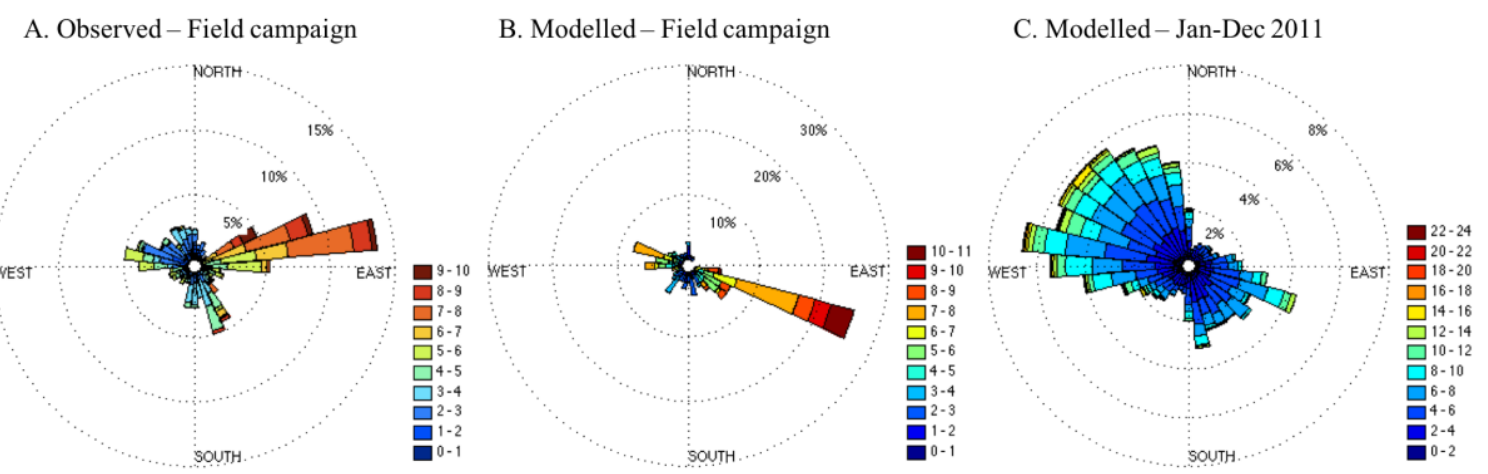

Figure 2 

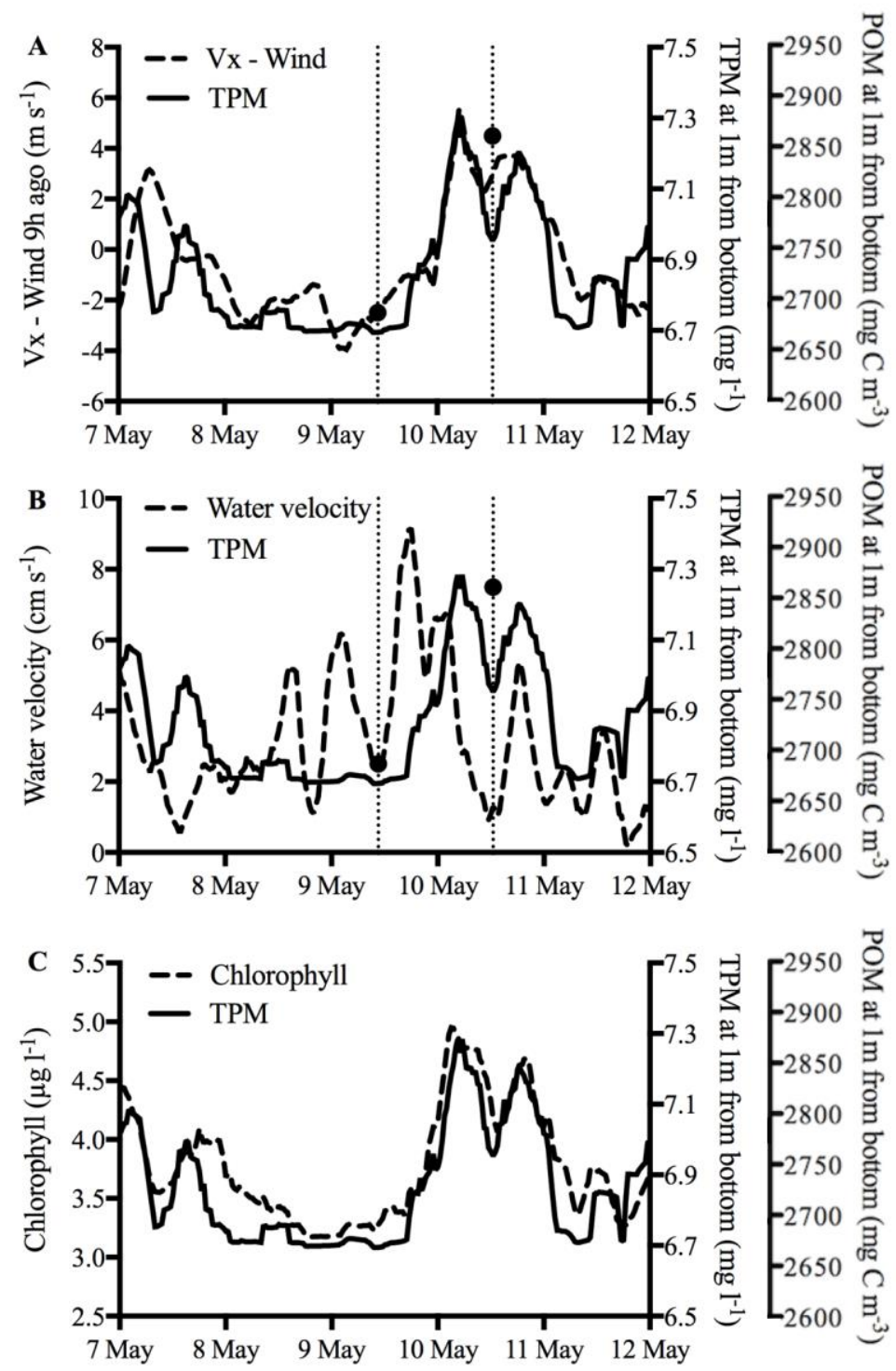

Figure 3 

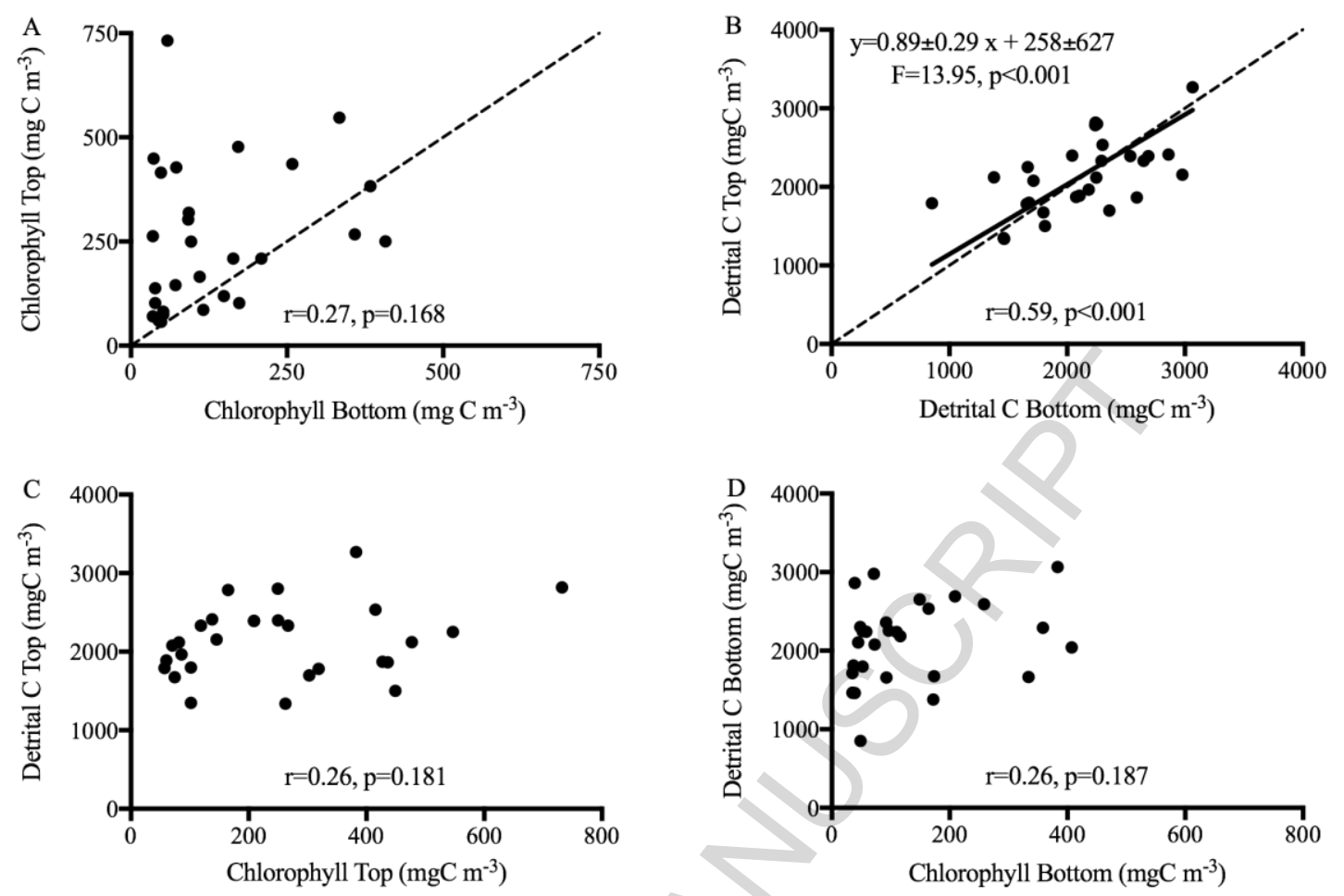

Figure 4 

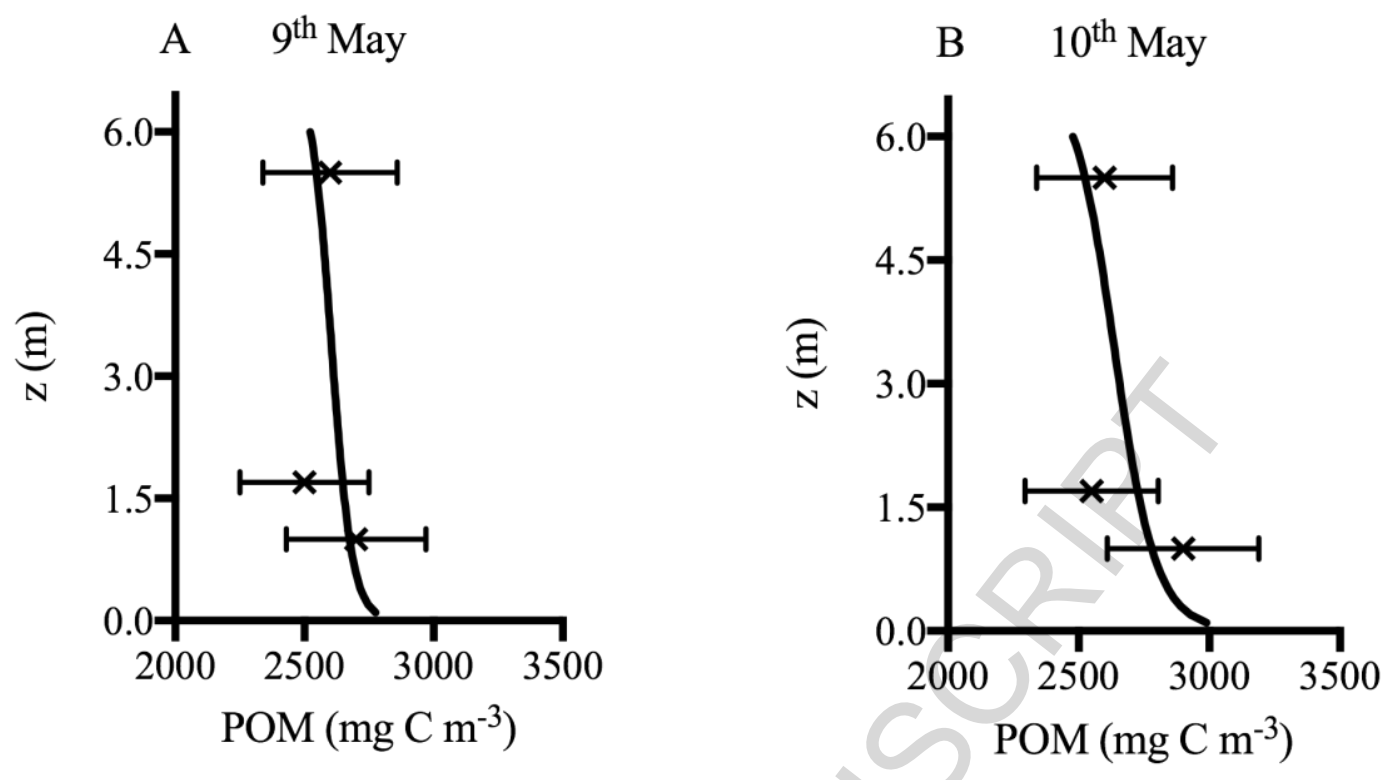

Figure 5 


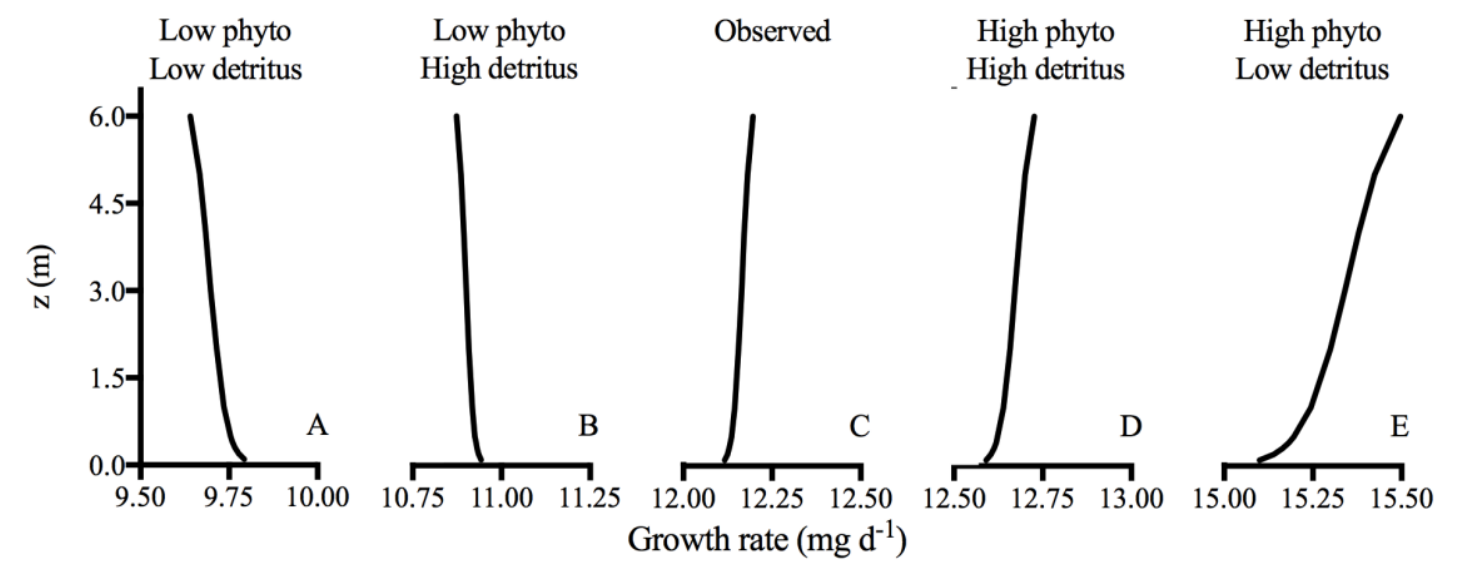

Figure 6 


\section{Highlights}

- Wind-forced resuspension could alter food availability for cultured bivalves

- Resuspended material may cause positive or negative impacts on bivalve growth

- Bivalve vertical positioning is key to benefit/mitigate the impact of resuspension

- Due to high background seston, resuspension does not alter available food in Skive

- DEB modelling suggests minimal effects of resuspended material on mussel growth 